\title{
Temporal geochemical and microbiological characterization of flowback and produced waters from mature and time-series wells, Niobrara Formation, Colorado USA
}

\author{
JENNA L. SHELTON ${ }^{1, *}$, KAELA AMUNDSON ${ }^{2}$, JESSICA \\ ChenaUlT $^{3}$, AARON M. JUBB ${ }^{3}$, Michael Wilkins ${ }^{2}$, \\ MADALYN BLONDES ${ }^{3}$, CHRISTINA DEVERA ${ }^{3}$
}

${ }^{1}$ U.S. Geological Survey, Sacramento, CA 95819

(*correspondence jlshelton@usgs.gov)

${ }^{2}$ Colorado State University, Fort Collins, CO 80523

${ }^{3}$ U.S. Geological Survey, Reston, VA 20192

Changes in produced water (PW) geochemistry and microbial communities over the lifespan of hydraulically fractured wells producing from the Niobrara Formation, Denver-Julesburg Basin in Colorado are not well understood, and therefore targeted water treatment processes may be difficult to implement across the entire basin. Additionally, understanding the distribution of microbes present across a reservoir may aid in future stimulation of methanogens for enhanced biogenic gas production. This study examines $16 \mathrm{~S}$ rRNA gene sequencing data, stable isotopes, and compositional geochemical data of PW from four hydraulically fractured wells over time, starting at day zero (day of frack). Sampling is still on-going over a year later. Additional mature wells ( $>1000$ days in production) have also been sampled to better understand steady-state dynamics in the Niobrara.

Flowback and PW ionic composition are dominated by $\mathrm{Na}$ and $\mathrm{Cl}$, with TDS concentrations ranging from 10,200 $\mathrm{mg} / \mathrm{L}$ on day 0 to $28,700 \mathrm{mg} / \mathrm{L}$ after 1000 days in production. The Niobrara PW took $>200$ days to reach a geochemical steady state compared to $<100$ days for other producing shales. Stable isotopes of water generally plot on or above the local meteoric water line throughout the sampling peroid, which could be attributed to methanogenesis.

Microbial community composition varies not only over time, but across and within producing units. PW from mature wells tends to have more stable and comparative microbial community structures than the younger time series wells. Mature wells are dominated by Thermotogae, Clostridia, Synergistia, and Deltaproteobacteria. None of the four younger wells, after $>330$ days in production, host microbial communities that are statistically similar to the mature wells, suggesting microbial communities take much longer to reflect in situ conditions than water chemistry data. 